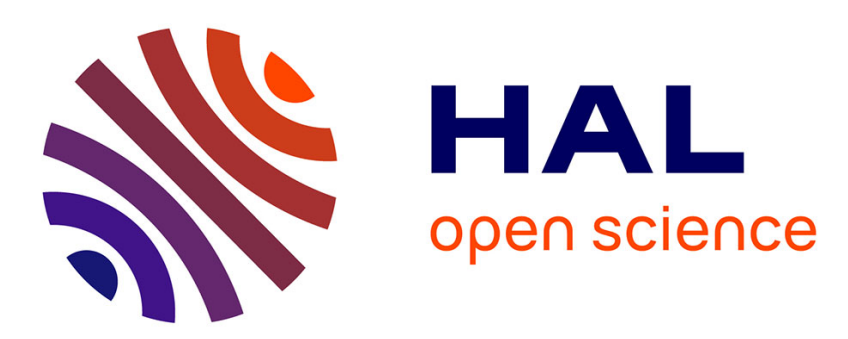

\title{
Aluminum substitution for vanadium in the Na3V2(PO4 )2F3 and Na3V2(PO4)2FO2 type materials
}

\author{
Jacob Olchowka, Long H. B. Nguyen, Thibault Broux, Paula Sanz Camacho, \\ Emmanuel Petit, François Fauth, Dany Carlier, Christian Masquelier, \\ Laurence Croguennec
}

\section{To cite this version:}

Jacob Olchowka, Long H. B. Nguyen, Thibault Broux, Paula Sanz Camacho, Emmanuel Petit, et al.. Aluminum substitution for vanadium in the Na3V2(PO4 )2F3 and Na3V2(PO4)2FO2 type materials. Chemical Communications, 2019, 55 (78), pp.11719-11722. 10.1039/C9CC05137F . hal-02294384

\section{HAL Id: hal-02294384 \\ https://hal.science/hal-02294384}

Submitted on 4 Oct 2019

HAL is a multi-disciplinary open access archive for the deposit and dissemination of scientific research documents, whether they are published or not. The documents may come from teaching and research institutions in France or abroad, or from public or private research centers.
L'archive ouverte pluridisciplinaire HAL, est destinée au dépôt et à la diffusion de documents scientifiques de niveau recherche, publiés ou non, émanant des établissements d'enseignement et de recherche français ou étrangers, des laboratoires publics ou privés. 


\section{Aluminum substitution for vanadium in the $\mathrm{Na}_{3} \mathrm{~V}_{2}\left(\mathrm{PO}_{4}\right)_{2} \mathrm{~F}_{3}$ and $\mathrm{Na}_{3} \mathrm{~V}_{2}\left(\mathrm{PO}_{4}\right)_{2} \mathrm{FO}_{2}$ type materials}

Received 00th January 20xx, Accepted 00th January 20xx

\author{
Jacob Olchowka ${ }^{\text {a,d,e }}$, Long H. B. Nguyen ${ }^{\mathrm{a}, \mathrm{b}, \mathrm{d}}$, Thibault Broux ${ }^{\mathrm{a}, \mathrm{b}, \mathrm{d}, \mathrm{e}}$, Paula Sanz Camacho ${ }^{\mathrm{a}, \mathrm{d}}$, Emmanuel
} Petit $^{\text {a,d,e }}$, François Fauth ${ }^{c}$, Dany Carlier ${ }^{\mathrm{a}, \mathrm{d}, \mathrm{e}}$, Christian Masquelier ${ }^{\mathrm{b}, \mathrm{d}, \mathrm{e}}$ Laurence Croguennec ${ }^{\mathrm{a}, \mathrm{d}, \mathrm{e}, *}$

DOI: $10.1039 / \times 0 \times x 00000 x$

Among the positive electrode materials for Na-ion batteries, $\mathrm{Na}_{3} \mathrm{~V}_{2}\left(\mathrm{PO}_{4}\right)_{2} \mathrm{~F}_{3}$ is considered as one of the most promising and generates high interest. Here, we study the influence of the sol-gel synthesis parameters on the structure and on the electrochemical signature of the partially substituted $\mathrm{Na}_{3} \mathrm{~V}_{2-2} \mathrm{Al}_{2}\left(\mathrm{PO}_{4}\right)_{2}(\mathrm{~F}, \mathrm{O})_{3}$ materials. We demonstrate that the acidity of the starting solution influences the vanadium oxidation state of the final product. For the first time we report on the possibility of controlling the double $\mathrm{Al} / \mathrm{V}$ and $\mathrm{O} / \mathrm{F}$ substitution that leads to the preparation of the $\mathrm{Na}_{3} \mathrm{~V}_{2-2} \mathrm{Al}_{2}\left(\mathrm{PO}_{4}\right)_{2} \mathrm{~F}_{1+2} \mathrm{O}_{2-z}$ solid solution.

These last years the booming electric and hybrid vehicle market conjugated to the development of renewable energy technologies have generated a strong interest in alternative electrochemical storage technologies to the Li-ion batteries. ${ }^{1}$ Among them, $\mathrm{Na}$-ion batteries are nowadays considered as a reliable and more eco-friendly alternative due to the high abundance of sodium widespread all over the Earth. Within the large panel of possible positive electrode materials, $\mathrm{Na}_{3} \mathrm{~V}_{2}\left(\mathrm{PO}_{4}\right)_{2} \mathrm{~F}_{3}$ (NVPF) is among the most promising ones due to its excellent stability upon long range electrochemical cycling and to its attractive high rate performances when coated with carbon that allows fast charge compared to the layered oxides $\mathrm{Na}_{x} \mathrm{MO}_{2}$ ( $\mathrm{M}=$ transition metal). ${ }^{2-4}$ Moreover, the reversible extraction of two sodium ions at a potential of $\sim 3.7 \mathrm{~V}\left(1^{\text {st }} \mathrm{Na}^{+}\right)$ and $4.2 \mathrm{~V}\left(2^{\text {nd }} \mathrm{Na}^{+}\right)$vs. $\mathrm{Na}^{+} / \mathrm{Na}$ leads to an energy density comparable to that of the commercial Li-ion batteries using $\mathrm{LiFePO}_{4}$ at the positive electrode $(507 \mathrm{Wh} / \mathrm{kg}$ for NVPF versus $530 \mathrm{Wh} / \mathrm{kg}$ for $\left.\mathrm{LiFePO}_{4}\right) .{ }^{5}$ Currently, NVPF is used as a positive electrode material by the start-up TIAMAT that develops and produces functional 18650 cells as Na-ion battery prototypes. Very recently, the attractiveness of NVPF increased even more

a CNRS, Univ. Bordeaux, Bordeaux INP, ICMCB UMR 5026, F-33600, Pessac, France. b Laboratoire de Réactivité et de Chimie des Solides, CNRS-UMR\# 7314, Université de Picardie Jules Verne, F-80039 Amiens Cedex 1, France.

c CELLS-ALBA synchrotron, E-08290 Cerdanyola del Vallès, Barcelona, Spain.

d RS2E, Réseau Français sur le Stockage Electrochimique de l'Energie, FR CNRS 3459,

F-80039 Amiens Cedex 1, France.

e ALISTORE-ERI European Research Institute, FR CNRS 3104, Amiens, F-80039 Cedex 1, France.

Electronic Supplementary Information (ESI) available: [details of any supplementary information available should be included here]. See DOI: 10.1039/x0xx00000x since Yan et al. demonstrated the possibility to increase the energy density of the full cell NVPF versus hard carbon of $\sim 14 \%$ by extracting more than two $\mathrm{Na}^{+}$at high potential and due to its promising performances reported in aqueous systems. ${ }^{6,7}$

In order to explore the possibility of modifying the values of the redox couples involved in the insertion/de-insertion reactions and thus the potential, the transport properties and the capacity retention at high rates, different approaches were explored. Anionic substitution of oxygen for fluorine has a significant impact on the crystal structure and electrochemical properties of $\mathrm{Na}_{3} \mathrm{~V}_{2}\left(\mathrm{PO}_{4}\right)_{2} \mathrm{~F}_{3-\mathrm{y}} \mathrm{O}_{y} \cdot{ }^{8-11}$ The richer the oxygen content, the lower the average discharge voltage and thus the energy densities are. Similarly, the effect of cationic doping/substitution for vanadium was studied using for instance yttrium, manganese, lanthanum or titanium in order to improve the electronic conductivity and $\mathrm{Na}^{+}$mobility. ${ }^{12-14}$

However, only few of these studies actually addressed the characterization of the composition and the structure of the materials as obtained, in relation with the electrochemical performance. Kosova et al. have demonstrated that Lanthanum substitution was in fact a surface modification effect by $\mathrm{LaPO}_{4} .^{15}$ The group of Ceder has studied gallium and aluminium substitution for vanadium, with the aim to disrupt the charge and $\mathrm{Na}^{+}$orderings within the lattice and thus lower the energy barrier for the reversible extraction of the $3^{\text {rd }} \mathrm{Na} .{ }^{16,17}$ Among the different metals, aluminium drew our attention as $\mathrm{Al}$ is cheaper, lighter, more environmentally friendly than $\mathrm{V}$ and, as a nonelectrochemically active element, could participate to the stabilization of the material upon cycling. Furthermore, the partial substitution of $0.5 \mathrm{Al}^{3+}$ for $\mathrm{V}$ in $\mathrm{Na}_{3} \mathrm{~V}^{3+}{ }_{2-2} \mathrm{Al}_{2}\left(\mathrm{PO}_{4}\right)_{2} \mathrm{~F}_{3}$ would lead to an increase of $\sim 3 \%$ of the theoretical gravimetric capacity for the reversible exchange of $2 \mathrm{Na}^{+}$ions, while keeping the extraction of the third $\mathrm{Na}^{+}$ion possible (i.e. for the exchange of $3 \mathrm{e}^{-}$or $\mathrm{Na}^{+}$ions per $1.5 \mathrm{~V}^{3+}$ in the pristine material). Bianchini et al. have reported an aluminium substitution for vanadium in NVPF limited to $z=0.3\left(\mathrm{Na}_{3} \mathrm{~V}_{1.7} \mathrm{Al}_{0.3}\left(\mathrm{PO}_{4}\right)_{2} \mathrm{~F}_{3}\right)$ through solid-state reaction. ${ }^{16}$ However, a loss of reversible capacity was observed for the substituted materials, as only the $\mathrm{V}^{3+} / \mathrm{V}^{4+}$ redox couple appeared to be involved in the redox processes in the potential range of $2-4.5 \mathrm{~V}$ vs. $\mathrm{Na}^{+} / \mathrm{Na}$. On the other hand, Lalère et al. interestingly demonstrated that the $\mathrm{V}^{4+} / \mathrm{V}^{5+}$ redox couple could 

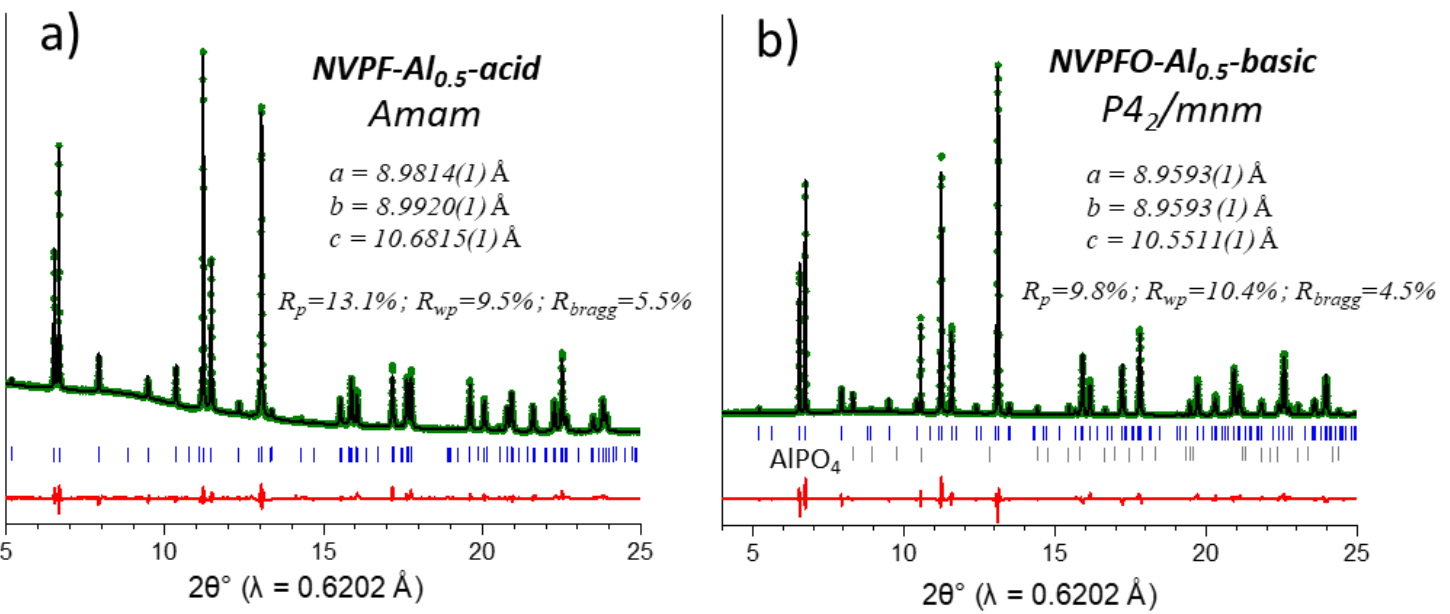

Figure 1. Rietveld refinement of synchrotron powder X-ray diffraction data recorded at $\lambda=0.6202 \AA$ for: a) NVPF-Al 0.5 -acidic refined in the Amam space group and b) NVPFO$\mathrm{Al}_{0.5}$-basic refined in the $P 4_{2} / \mathrm{mnm}$ space group. The secondary phase (bottom grey tick lines) corresponds to $\mathrm{AlPO}_{4}$ and its concentration is refined to $\sim 12.1$ wt.\%.

be activated in the partially substituted NASICON $\mathrm{Na}_{3} \mathrm{~V}_{1.5} \mathrm{Al}_{0.5}\left(\mathrm{PO}_{4}\right)_{3}$ at an average voltage of $3.95 \mathrm{~V}$ vs Na$/ \mathrm{Na}^{18}$

In order to increase the Al-content in the substituted phases, $\mathrm{Na}_{3} \mathrm{~V}_{2-\mathrm{z}} \mathrm{Al}_{2}\left(\mathrm{PO}_{4}\right)_{2} \mathrm{~F}_{3}$, we here employed a sol-gel synthesis approach that allows a better chemical homogeneity of the precursors and leads to a higher material purity than through a traditional ceramic approach. ${ }^{19}$ We performed the synthesis in acidic and basic media in order to study the effects of the $\mathrm{pH}$ on the crystal structure and on the electrochemical performances of the phases obtained.

For the synthesis of $\mathrm{Na}_{3} \mathrm{~V}_{1.5} \mathrm{Al}_{0.5}\left(\mathrm{PO}_{4}\right)_{2} \mathrm{~F}_{3}$ in acidic medium (NVPF-Al 0.5 -acidic), citric acid monohydrate, $\mathrm{NH}_{4} \mathrm{VO}_{3}$ and $\mathrm{Al}\left(\mathrm{NO}_{3}\right)_{3} .9 \mathrm{H}_{2} \mathrm{O}$ with an appropriate molar ratio $2: 1.5: 0.5$ were first dissolved in a Teflon beaker containing about $100 \mathrm{~mL}$ of $\mathrm{H}_{2} \mathrm{O}$. Then, $\mathrm{NH}_{4} \mathrm{H}_{2} \mathrm{PO}_{4}$ and $\mathrm{NaF}$ (5\% in excess), were successively and slowly added to the solution. Once the solution turned green, which corresponded to the reduction of $\mathrm{V}^{5+}$ to $\mathrm{V}^{3+}$, it was heated overnight at $80^{\circ} \mathrm{C}$ under continuous stirring, resulting in a beige/dark powder. This powder was finely ground, placed in a golden crucible, and heated at $350^{\circ} \mathrm{C}$ during $4 \mathrm{~h}$ to eliminate the volatile species. The as-obtained powder was subjected to a second calcination at $650^{\circ} \mathrm{C}$ during $10 \mathrm{~h}$ under continuous argon flow. Finally, the resulting black powder was washed in water to eliminate possible soluble impurities. The chemical composition of NVPF-Al 0.5 -acidic was confirmed by ICP-OES (Inductively Coupled Plasma - optical emission spectrometry) with $\mathrm{Na}: \mathrm{V}: \mathrm{Al}: \mathrm{P}$ cationic ratios of $3: 1.5: 0.5: 2$. Several attempts were made to further extend the $\mathrm{Na}_{3} \mathrm{~V}_{2-2} \mathrm{Al}_{2}\left(\mathrm{PO}_{4}\right)_{2} \mathrm{~F}_{3}$ solidsolution at $z$ values higher than $z=0.5$, with limited success. Most of the time, a mixture of $\mathrm{Na}_{3} \mathrm{~V}_{2}\left(\mathrm{PO}_{4}\right)_{2} \mathrm{~F}_{3}, \mathrm{Na}_{3} \mathrm{Al}_{2}\left(\mathrm{PO}_{4}\right)_{2} \mathrm{~F}_{3}$, $\mathrm{AlPO}_{4}$ and NASICON-type $\mathrm{Na}_{3} \mathrm{~V}_{2}\left(\mathrm{PO}_{4}\right)_{3}$ were obtained. The crystal structure of NVPF-Al 0.5 -acidic was determined by Rietveld refinement using high-resolution synchrotron powder $X$-ray data (SXRD) from the ALBA synchrotron facility (see Figure 1a). As for NVPF, NVPF-Al 0.5 -acidic presents a subtle orthorhombic distortion, which is described in the Amam space group (see Figures 1a and S1-S2, Tables S1-S2).20 A shrinkage of the cell volume is observed in the NVPF-Al 0.5 -acidic phase $\left(862.65(1) \AA^{3}\right.$ vs. 877.54(1) $\AA^{3}$ for NVPF), which is due to the smaller ionic radius of $\mathrm{Al}^{3+}$ vs. $\mathrm{V}^{3+}$ (respectively $0.535 \AA$ and $0.64 \AA$ in an octahedral coordination) (see Table S3 and Figure 2a-b).
The use of $\mathrm{NaF}$ in acidic media may leads to $\mathrm{HF}$ release, which is a volatile species that can easily evaporate at $80^{\circ} \mathrm{C}$. In order to minimize the possible departure of harmful $\mathrm{HF}$ during the evaporation step, which may be the cause of the formation of NASICON-type phases, the synthesis procedure was further modified by using a $\mathrm{NH}_{4} \mathrm{OH}\left(28-30 \% \mathrm{NH}_{3}\right.$ basis) buffer solution to adjust the $\mathrm{pH}$ of the solution at $\sim 9.2$ during the dissolution process. By controlling the $\mathrm{pH}$, the solution quickly turned into blue indicating the possible presence of $\mathrm{V}^{4+}$. Thanks to this modified method, a new family of Al-substituted phases, $\mathrm{Na}_{3} \mathrm{~V}_{2}$ ${ }_{2} \mathrm{Al}_{z}\left(\mathrm{PO}_{4}\right)_{2} \mathrm{~F}_{1+z} \mathrm{O}_{2-z}(0 \leq \mathrm{z} \leq 2)$, was obtained (Figures S3-S4 and Table S3). AlPO ${ }_{4}$ is present as an impurity in some samples; however, this does not hinder the structural determination of the main phase by the use of Rietveld refinement. Figure $1 \mathrm{~b}$ illustrates the SXRPD Rietveld refinement analysis of $\mathrm{Na}_{3} \mathrm{~V}_{1.5} \mathrm{Al}_{0.5}\left(\mathrm{PO}_{4}\right)_{2} \mathrm{~F}_{1.5} \mathrm{O}_{1.5}$ synthesized in basic medium, called NVPFO-Al 0.5 -basic. This phase crystallizes in the tetragonal $\mathrm{P}_{2} / \mathrm{mnm}$ space group. The reliability factors $\left(\mathrm{R}_{\mathrm{Bragg}}=4.5 \%\right.$ and $\mathrm{R}_{\mathrm{wp}}=10.4 \%$ ) demonstrate the good quality of the Rietveld refinement despite the presence of $\mathrm{AlPO}_{4}$ as a secondary phase (up to 12.1 wt.\%) (Tables S4-S5). The cell parameters determined for the $\mathrm{V}^{4+}$-rich phase $\mathrm{Na}_{3} \mathrm{~V}_{1.5} \mathrm{Al}_{0.5}\left(\mathrm{PO}_{4}\right)_{2} \mathrm{~F}_{1.5} \mathrm{O}_{1.5}$ are $\mathrm{a}=8.9593(1) \AA$ and $\mathrm{c}=10.5511$ (1) $\AA$ with a cell volume $\mathrm{V}=$ 846.93(1) $\AA^{3}$, significantly smaller than those reported for the corresponding $\mathrm{V}^{3+}$-rich phase $\mathrm{Na}_{3} \mathrm{~V}_{1.5} \mathrm{Al}_{0.5}\left(\mathrm{PO}_{4}\right)_{2} \mathrm{~F}_{3}$ (Table S3). Elemental analysis performed by ICP-OES leads to a cationic

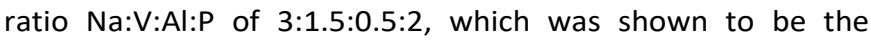
composition of the main NVPF-type phase despite the presence of $\mathrm{AlPO}_{4}$ as impurity. Indeed, this latter is sparsely soluble in $\mathrm{HCl}$ solution, the acid used for the sample dissolution required to perform the chemical analyses (see supplementary information). Figure $2 \mathrm{~b}$ shows a linear evolution of the cell parameter $\mathrm{c}$ (along the bioctahedral unit, see Figure 2a) for all the phases $\mathrm{Na}_{3} \mathrm{~V}_{2-z} \mathrm{Al}_{2}\left(\mathrm{PO}_{4}\right)_{2} \mathrm{~F}_{1+z} \mathrm{O}_{2-z}(0 \leq z \leq 2)$ implying a solidsolution formation according to Vegard's law. Interestingly, starting from the same $\mathrm{V}: \mathrm{Al}$ ratio $\left(\mathrm{V}_{1.5} \mathrm{Al}_{0.5}\right)$ and monitoring the sol-gel synthesis conditions in acidic and basic media, two original materials could be obtained: $\mathrm{Na}_{3} \mathrm{~V}^{3+}{ }_{1.5} \mathrm{Al}^{3+}{ }_{0.5}\left(\mathrm{PO}_{4}\right)_{2} \mathrm{~F}_{3}$ and $\mathrm{Na}_{3} \mathrm{~V}^{4+}{ }_{1.5} \mathrm{Al}^{3+}{ }_{0.5}\left(\mathrm{PO}_{4}\right)_{2} \mathrm{~F}_{1.5} \mathrm{O}_{1.5}$. The first composition maintains the same structure as NVPF, with a small orthorhombic distortion (b/a 1.002) and $\mathrm{Na}^{+}$ions distributed among three different sites in the tunnels, whereas the second one is also stabilized in a structure close to that of NVPF, but described in 


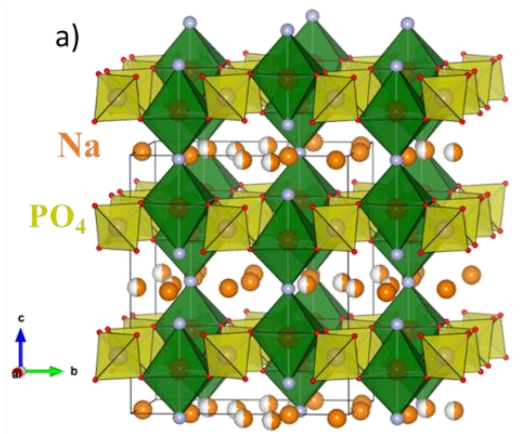

$(\mathrm{V} / \mathrm{Al}) \mathrm{O}_{4}(\mathrm{~F}, \mathrm{O})_{2}$
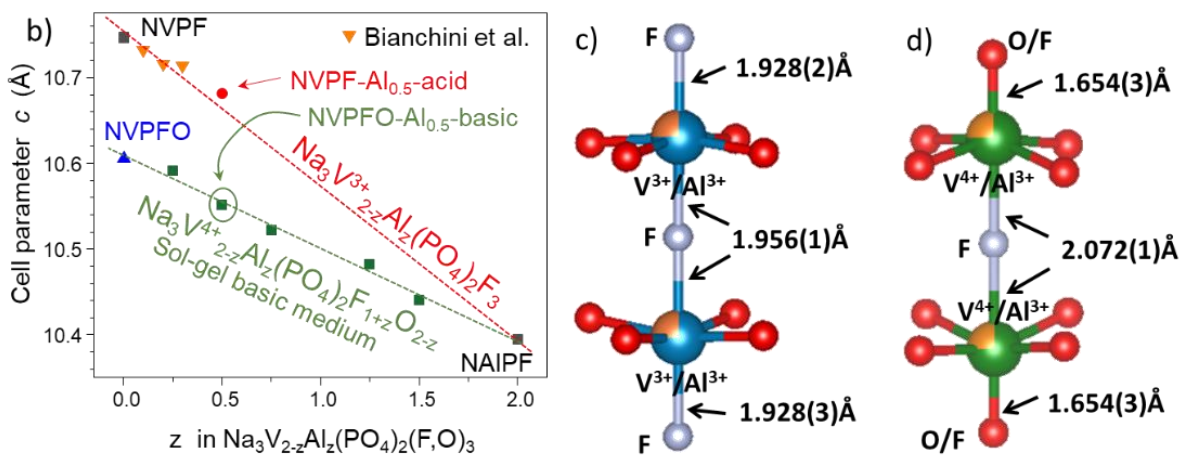

Figure 2. a) Representation of the $\mathrm{Na}_{3}(\mathrm{~V}, \mathrm{Al})_{2}\left(\mathrm{PO}_{4}\right)_{2}(\mathrm{~F}, \mathrm{O})_{3}$ crystal structure; $\left.b\right)$ Evolution of the $\mathrm{c}$ unit cell parameter of $\mathrm{Al}$-substituted $\mathrm{Na}_{3} \mathrm{~V}_{2-2} \mathrm{Al}_{2}\left(\mathrm{PO}_{4}\right)_{2}(\mathrm{~F}, \mathrm{O})_{3}$ phases as a function of

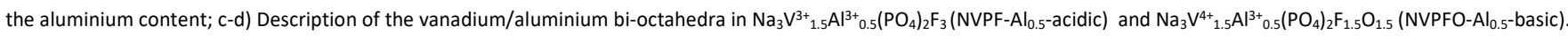

a tetragonal unit cell with only two sites for the $\mathrm{Na}^{+}$ions. In order to get more insight into the difference in cell parameters between NVPF-Al 0.5 -acidic and NVPFO-Al 0.5 -basic, the environments of $\mathrm{V}(\mathrm{Al})$ in the two structures were compared, based on the structural determination performed by Rietveld refinement. The major difference was observed for the apical $\mathrm{V} / \mathrm{Al}-(\mathrm{F}, \mathrm{O})$ bond lengths along the bi-octahedral units $(\mathrm{V}, \mathrm{Al})_{2} \mathrm{O}_{8}(\mathrm{~F}, \mathrm{O})_{3}$. As described in Figure $2 \mathrm{c}$, the terminal $\mathrm{V} / \mathrm{Al}-\mathrm{F}$ bonds of the bi-octahedra $\mathrm{V}_{1.5} \mathrm{Al}_{0.5} \mathrm{O}_{8} \mathrm{~F}_{3}$ observed in NVPF-Al 0.5 -acidic are of 1.928(2) $\AA$ which is in good accordance with the common value found for a $\mathrm{Al} / \mathrm{V}^{3+}-\mathrm{F}$ bond. On the other hand, the terminal V/AI-O/F bond lengths are estimated to be of 1.654(3) $\AA$ in NVPFO-Al $\left.\right|_{0.5}$-basic, which fits well with an average distance corresponding to the contribution of $25 \%$ of
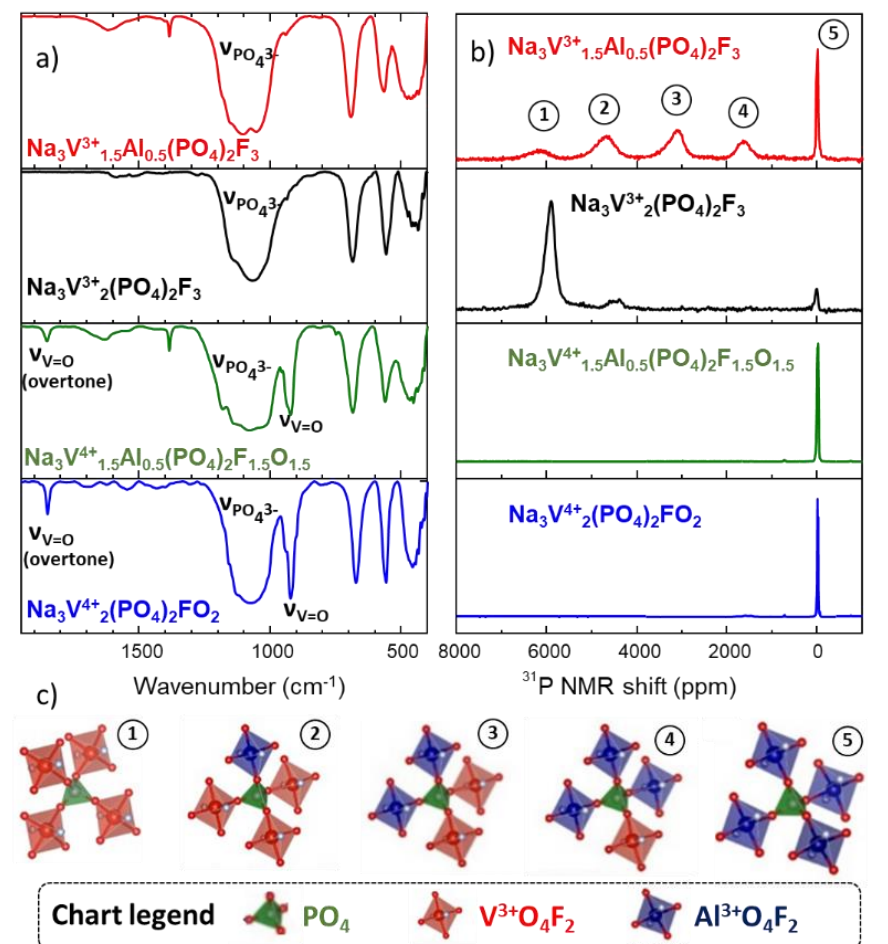

Figure 3. a) FTIR spectra of $\mathrm{Na}_{3} \mathrm{~V}^{3+}{ }_{1.5} \mathrm{Al}_{0.5}\left(\mathrm{PO}_{4}\right)_{2} \mathrm{~F}_{3}$ (red spectrum) assigned to be $\mathrm{Na}_{3} \mathrm{~V}_{1.5} \mathrm{Al}_{0.5}\left(\mathrm{PO}_{4}\right)_{2} \mathrm{~F}_{3}, \mathrm{Na}_{3} \mathrm{~V}_{2}\left(\mathrm{PO}_{4}\right)_{2} \mathrm{~F}_{3}$ (black spectrum $\mathrm{Na}_{3} \mathrm{~V}^{4+}{ }_{1.5} \mathrm{Al}_{0.5}\left(\mathrm{PO}_{4}\right)_{2} \mathrm{~F}_{1.5} \mathrm{O}_{1.5}$ (green spectrum) assigned to be $\mathrm{Na}_{3} \mathrm{~V}_{1.5} \mathrm{Al}_{0.5}\left(\mathrm{PO}_{4}\right)_{2} \mathrm{~F}_{1.5} \mathrm{O}_{1.5}$, and $\mathrm{Na}_{3} \mathrm{~V}_{2}\left(\mathrm{PO}_{4}\right)_{2} \mathrm{FO}_{2}$ (blue spectrum) recorded in the wavenumber range $400-1990 \mathrm{~cm}^{-1} \mathrm{~b}$ ) ${ }^{31} \mathrm{P}$ ss-NMR spectra of NVPF-Al 0.5 acid (red spectrum), $\mathrm{Na}_{3} \mathrm{~V}_{2}\left(\mathrm{PO}_{4}\right)_{2} \mathrm{~F}_{3}$ (black spectrum), NVPFO-Al $0_{0.5}$-basic (green spectrum), and $\mathrm{Na}_{3} \mathrm{~V}_{2}\left(\mathrm{PO}_{4}\right)_{2} \mathrm{FO}_{2}$ (blue spectrum) recorded at $100 \mathrm{MHz}, \mathrm{MAS}=30 \mathrm{kHz}$ c) The phosphorus environments corresponding to the five ss-NMR signals detected.
Al-F bonds close to $1.82 \AA$ and of $75 \%$ of $\mathrm{V}^{4+}=\mathrm{O}$ vanadyl bonds close to $1.6 \AA$ A. $^{21}$

As oxygen and fluorine cannot be distinguished by $\mathrm{X}$-ray diffraction and cannot be easily titrated by chemical analyses, analyses by Fourier Transformed Infrared (FTIR) and ${ }^{31} \mathrm{P}$ solidstate Nuclear Magnetic Resonance (ss-NMR) spectroscopies were performed and compared to those of $\mathrm{Na}_{3} \mathrm{~V}^{3+}{ }_{2}\left(\mathrm{PO}_{4}\right)_{2} \mathrm{~F}_{3}$ and $\mathrm{Na}_{3} \mathrm{~V}^{4+}{ }_{2}\left(\mathrm{PO}_{4}\right)_{2} \mathrm{FO}_{2}$ as reference compounds. The absence of vibration bands characteristic of $\mathrm{V}_{\mathrm{V}=\mathrm{O}}$ (vanadyl bond) at $\sim 919$ $\mathrm{cm}^{-1}$ in the IR spectrum of NVPF-Al 0.5 -acidic confirms that the material contains only $\mathrm{V}^{3+}$ (Figure $3 a$ ) confirming the $\mathrm{Na}_{3} \mathrm{~V}^{3+}{ }_{1.5} \mathrm{Al}_{0.5}\left(\mathrm{PO}_{4}\right)_{2} \mathrm{~F}_{3}$ composition. Additionally, the ${ }^{31} \mathrm{P}$ ss-NMR spectrum of $\mathrm{Na}_{3} \mathrm{~V}^{3+}{ }_{1.5} \mathrm{Al}_{0.5}\left(\mathrm{PO}_{4}\right)_{2} \mathrm{~F}_{3}$ exhibits 5 signals which can be attributed to phosphorus surrounded by different numbers of $\mathrm{V}^{3+}$ in its first cationic coordination sphere (the signals at $\sim 6000 \mathrm{ppm}, \sim 4500 \mathrm{ppm}, \sim 3000 \mathrm{ppm}, \sim 1500 \mathrm{ppm}$ and $\sim 0 \mathrm{ppm}$ are attributed to $\mathrm{P}\left(\mathrm{OV}^{3+}\right)_{4}, \mathrm{P}\left(\mathrm{OV}^{3+}\right)_{3}\left(\mathrm{OAl}^{3+}\right), \mathrm{P}\left(\mathrm{OV}^{3+}\right)_{2}\left(\mathrm{OAl}^{3+}\right)_{2}$, $\mathrm{P}\left(\mathrm{OV}^{3+}\right)\left(\mathrm{OAl}^{3+}\right)_{3}$ and $\mathrm{P}\left(\mathrm{OAl}^{3+}\right)_{4}$ local environments, respectively). Based on our ${ }^{31} \mathrm{P}$ MAS NMR study of the $\mathrm{Na}_{3} \mathrm{~V}^{3+}{ }_{2-y} \mathrm{~V}^{4+}{ }_{\mathrm{y}}\left(\mathrm{PO}_{4}\right)_{2} \mathrm{~F}_{3-}$ ${ }_{y} \mathrm{O}_{\mathrm{y}}$ phases, a $\mathrm{V}^{3+}$ octahedra sharing a corner with $\mathrm{PO}_{4}$ tetrahedra results in a Fermi contact interaction of about $1500 \mathrm{ppm}$, whereas a $\mathrm{V}^{4+}$ one do not lead to any shift contribution. ${ }^{8}$ Here, a $\mathrm{Al}^{3+}$ ion that does not possess unpaired electrons does not contribute to any Fermi contact shift and thus behave similarly as a $\mathrm{V}^{4+}$ ions in the lattice. Based on the relative signal intensities, the $\mathrm{Al}^{3+} / \mathrm{V}^{3+}$ ionic distribution in the material is close to the statistical one. On the other hand, as for the reference $\mathrm{Na}_{3} \mathrm{~V}^{4+}{ }_{2}\left(\mathrm{PO}_{4}\right)_{2} \mathrm{FO}_{2}$ (blue spectrum), NVPFO-Al $\mathrm{O}_{0.5}-$ basic (green spectrum) displays only a diamagnetic signal at $\sim 0$ $\mathrm{ppm}$ (see Figure $3 \mathrm{~b}$ ). This observation confirms the absence of $\mathrm{V}^{3+}$ in the structure. Concomitantly, the FTIR spectrum of NVPFO-Al 0.5 -basic exhibits intense bands centred at $\sim 925 \mathrm{~cm}^{-1}$ and its overtone at $1850 \mathrm{~cm}^{-1}$ revealing the presence of vanadyl bonds and hence, $\mathrm{V}^{4+}$ in the structure, which confirms the $\mathrm{Na}_{3} \mathrm{~V}^{4+}{ }_{1.5} \mathrm{Al}_{0.5}\left(\mathrm{PO}_{4}\right)_{2} \mathrm{~F}_{1.5} \mathrm{O}_{1.5}$ formula (see Figure $3 \mathrm{a}$ ). ${ }^{22}$

The electrochemical signatures of the $\mathrm{Na}_{3} \mathrm{~V}^{3+}{ }_{1.5} \mathrm{Al}_{0.5}\left(\mathrm{PO}_{4}\right)_{2} \mathrm{~F}_{3}$ and $\mathrm{Na}_{3} \mathrm{~V}^{4+}{ }_{1.5} \mathrm{Al}_{0.5}\left(\mathrm{PO}_{4}\right)_{2} \mathrm{~F}_{1.5} \mathrm{O}_{1.5}$ were studied in half cells vs. $\mathrm{Na}$ and compared to those of $\mathrm{Na}_{3} \mathrm{~V}^{3+}{ }_{2}\left(\mathrm{PO}_{4}\right)_{2} \mathrm{~F}_{3}$ (carbon-coated) and $\mathrm{Na}_{3} \mathrm{~V}^{4+}{ }_{2}\left(\mathrm{PO}_{4}\right)_{2} \mathrm{FO}_{2}$. Figure 4a displays the charge/discharge data of the four materials in the potential range $2.8-4.5 \mathrm{~V} \mathrm{vs}$. $\mathrm{Na}^{+} / \mathrm{Na}$ and at a cycling rate of $\mathrm{C} / 10$ per $\mathrm{Na}^{+}$. For $\mathrm{Na}_{3} \mathrm{~V}^{3+}{ }_{1.5} \mathrm{Al}_{0.5}\left(\mathrm{PO}_{4}\right)_{2} \mathrm{~F}_{3}$, the charge is characterized by two "sloping plateaus" at average potentials of $3.69 \mathrm{~V}$ and $4.23 \mathrm{~V}$ vs. $\mathrm{Na}^{+} / \mathrm{Na}$, which respectively correspond to the extraction of 1 and $0.5 \mathrm{Na}^{+}$. The polarization is much greater than for NVPF, as more extensively discussed in the supplementary information, and the "plateaus" are more sloping as indicated by the broad peaks observed on the first derivative data (see Figure 4b). The high polarization induces 
significant capacity loss between the charge and discharge and the sloping "plateaus" reveal a solid-solution type mechanism upon insertion and desinsertion of $\mathrm{Na}^{+}$whereas intermediate phases and biphasic domains are observed for NVPF. The extraction of $1.5 \mathrm{Na}^{+}$suggests that only the $\mathrm{V}^{3+} / \mathrm{V}^{4+}$ redox couple can be activated in the electrolyte stability window (up to $4.5 \mathrm{~V}$ vs. $\mathrm{Na}^{+} / \mathrm{Na}$ ) and the structural distortion in the bioctahedra induced by $\mathrm{V} / \mathrm{Al}$ substitution does not allow the activation of the $\mathrm{V}^{4+} / \mathrm{V}^{5+}$ redox couple in this potential range. The extra-capacity obtained at high potential ( $>4.5 \mathrm{~V}$ vs. $\mathrm{Na}^{+} / \mathrm{Na}$ ) (Figure S5) is not completely reversible and is discussed in the supplementary part S5).

The electrochemical signature of $\mathrm{Na}_{3} \mathrm{~V}^{4+}{ }_{1.5} \mathrm{Al}_{0.5}\left(\mathrm{PO}_{4}\right)_{2} \mathrm{~F}_{1.5} \mathrm{O}_{1.5}$ is also characterized by two "plateaus" corresponding to the reversible extraction of $\sim 1 \mathrm{Na}^{+}$and $0.5 \mathrm{Na}^{+}$at average potentials of $\sim 3.66$ and $4.05 \mathrm{~V}$ vs. $\mathrm{Na}^{+} / \mathrm{Na}$ respectively. Compared to $\mathrm{Na}_{3} \mathrm{~V}^{4+}{ }_{2}\left(\mathrm{PO}_{4}\right)_{2} \mathrm{FO}_{2}$, the $\mathrm{Na}^{+}$extraction voltage in $\mathrm{Na}_{3} \mathrm{~V}^{4+}{ }_{1.5} \mathrm{Al}_{0.5}\left(\mathrm{PO}_{4}\right)_{2} \mathrm{~F}_{1.5} \mathrm{O}_{1.5}$ is not affected by the Al-substitution. However, the polarization increases significantly leading to a reduction in the efficiency of the electrode material. The reversible extraction of $1.5 \mathrm{Na}^{+}$shows that the $(\mathrm{V}=\mathrm{O})^{2+} /(\mathrm{V}=\mathrm{O})^{3+}$ redox couple (or $\mathrm{V}^{4+} / \mathrm{V}^{5+}$ with $\mathrm{V}$ engaged in vanadyl bonds) could be activated, on the contrary to the $\mathrm{V}^{4+} / \mathrm{V}^{5+}$ engaged in $\mathrm{V}-\mathrm{F}$ bonds. For $\mathrm{Na}_{3} \mathrm{~V}^{4+}{ }_{1.5} \mathrm{Al}_{0.5}\left(\mathrm{PO}_{4}\right)_{2} \mathrm{~F}_{1.5} \mathrm{O}_{1.5}$, the theoretical capacity is experimentally delivered.

To summarize, we succeeded to synthesize a highly substituted ( $\mathrm{Al}$ for $\mathrm{V}$ ) range of compositions in the $\mathrm{Na}_{3} \mathrm{~V}^{3+}{ }_{1.5} \mathrm{Al}_{0.5}\left(\mathrm{PO}_{4}\right)_{2} \mathrm{~F}_{3}$ solid-solution and reported for the first time the controlled synthesis of a series of combined anionic and cationic substituted positive electrode materials of general formula: $\mathrm{Na}_{3} \mathrm{~V}^{4+}{ }_{2-z} \mathrm{Al}_{2}\left(\mathrm{PO}_{4}\right)_{2} \mathrm{~F}_{1+z} \mathrm{O}_{2-z}(0<z<2)$. The Al for $\mathrm{V}$ substitution has a minor effect on the average potential of the $\mathrm{Na}^{+}$extraction, on the contrary to $\mathrm{F} / \mathrm{O}$ substitution that strongly lowers the extraction potential of the high voltage plateau $\left(2^{\text {nd }} \mathrm{Na}^{+}\right)$. For $\mathrm{Na}_{3} \mathrm{~V}^{3+}{ }_{1.5} \mathrm{Al}_{0.5}\left(\mathrm{PO}_{4}\right)_{2} \mathrm{~F}_{3}$, although the $\mathrm{V} / \mathrm{Al}$ partial substitution increases the theoretical gravimetric capacity, only the $\mathrm{V}^{3+} / \mathrm{V}^{4+}$ redox couple could be activated in the potential range $2.8-4.5 \mathrm{~V}$ vs. $\mathrm{Na}^{+} / \mathrm{Na}$ which lowers the specific energy.
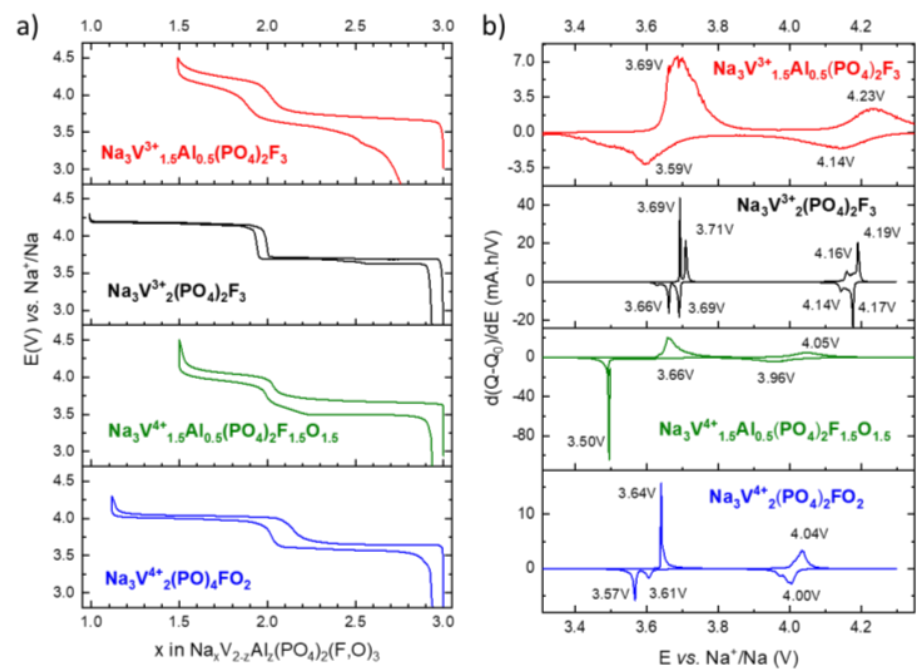

Figure 4 a) Charge/discharge galvanostatic data for $\mathrm{Na}_{3} \mathrm{~V}_{1.5} \mathrm{Al}_{0.5}\left(\mathrm{PO}_{4}\right)_{2} \mathrm{~F}_{3}, \mathrm{Na}_{3} \mathrm{~V}_{2}\left(\mathrm{PO}_{4}\right)_{2} \mathrm{~F}_{3}$ $\mathrm{Na}_{3} \mathrm{~V}_{1.5} \mathrm{Al}_{0.5}\left(\mathrm{PO}_{4}\right)_{2} \mathrm{~F}_{1.5} \mathrm{O}_{1.5}$, and $\mathrm{Na}_{3} \mathrm{~V}_{2}\left(\mathrm{PO}_{4}\right)_{2} \mathrm{FO}_{2}$ at a cycling rate of $\mathrm{C} / 10$ per $\mathrm{Na}^{+}$. The materials were cycled versus $\mathrm{Na}$ metal in $1 \mathrm{M} \mathrm{NaPF}_{6}$ in EC : DMC $=1: 1$ with 2 wt.\% of FEC; b) The first derivative of the corresponding electrochemical data.

On the other hand, the theoretical capacity is reached for $\mathrm{Na}_{3} \mathrm{~V}^{4+}{ }_{1.5} \mathrm{Al}_{0.5}\left(\mathrm{PO}_{4}\right)_{2} \mathrm{~F}_{1.5} \mathrm{O}_{1.5}$. These results confirm also that the
$(\mathrm{V}=\mathrm{O})^{2+} /(\mathrm{V}=\mathrm{O})^{3+}$ redox couple (or $\mathrm{V}^{4+} / \mathrm{V}^{5+}$ with $\mathrm{V}$ engaged in vanadyl bonds) could be reversibly activated in the stability window of current electrolytes, on the contrary to the $\mathrm{V}^{4+} / \mathrm{V}^{5+}$ engaged in $\mathrm{V}-\mathrm{F}$ bonds. These solid solutions call to be scrutinized much more in details to determine the substitution in $\mathrm{Al}$ and $\mathrm{O}$ just sufficient to optimize the properties of the very attractive electrode material for $\mathrm{Na}$-ion batteries, $\mathrm{Na}_{3} \mathrm{~V}_{2}\left(\mathrm{PO}_{4}\right)_{2} \mathrm{~F}_{3}$, the panel of properties being well beyond the reversible capacity only. Indeed, the chemical and thermal stability in the charge state of the battery is for instance one of them, as controlling the safety of the battery but also the long range cyclability.

The authors thank the RS2E and Alistore-ERI Networks for the funding of LHBN's PhD thesis and TB's postdoctoral fellowship, as well as the financial support of Région Nouvelle Aquitaine, of the French National Research Agency (STORE-EX Labex Project ANR-10-LABX-76-01 and SODIUM Descartes project ANR-13-DESC-0001-02) and of H2020 research and innovation program under the Grant Agreement No. 646433-NAIADES. The authors also want to thank C.DENAGE, A. FARGUES and E.LEBRAUD (ICMCB) for their help with SEM, FTIR and XRD analyses, respectively.

\section{Conflicts of interest}

There are no conflicts of interest to declare.

\section{Notes and references}

1 D. Larcher and J. M. Tarascon, Nat. Chem., 2015, 7, 19-29.

2 T. Broux, F. Fauth, N. Hall, Y. Chatillon, M. Bianchini, T. Bamine, J.-B. Leriche, E. Suard, D. Carlier, Y. Reynier, L. Simonin, C. Masquelier and L. Croguennec, Small Methods, 2018, 2, 1800215.

3 C. Zhu, C. Wu, C. C. Chen, P. Kopold, P. A. Van Aken, J. Maier and Y. Yu, Chem. Mater., 2017, 29, 5207-5215.

4 C. Masquelier and L. Croguennec, Chem. Rev., 2013, 113, 6552-6591.

5 B. Senthilkumar, C. Murugesan, L. Sharma, S. Lochab and P. Barpanda, Small Methods, 2018, 3, 1800253.

6 G. Yan, S. Mariyappan, G. Rousse, Q. Jacquet, M. Deschamps, R. David, B. Mirvaux, J. W. Freeland and J.-M. Tarascon, Nat. Commun., 2019, 10, 585. 7 P. R. Kumar, Y. H. Jung, C. H. Lim and D. K. Kim, J. Mater. Chem. A, 2015, 3, 6271-6275.

8 T. Broux, T. Bamine, F. Fauth, L. Simonelli, W. Olszewski, C. Marini, M. Ménétrier, D. Carlier, C. Masquelier and L. Croguennec, Chem. Mater., 2016, 28, 7683-7692.

9 P. Serras, V. Palomares, J. Alonso, N. Sharma, J. M. López Del Amo, P. Kubiak, M. L. Fdez-Gubieda and T. Rojo, Chem. Mater., 2013, 25, 4917-4925. 10 Y. U. Park, D. H. Seo, H. S. Kwon, B. Kim, J. Kim, H. Kim, I. Kim, H. I. Yoo and K. Kang, J. Am. Chem. Soc., 2013, 135, 13870-13878.

11 L. H. B. Nguyen, T. Broux, P. S. Camacho, D. Denux, L. Bourgeois, S. Belin, A. ladecola, F. Fauth, D. Carlier, J. Olchowka, C. Masquelier and L. Croguennec, Energy Storage Mater., 2019, 20, 324-334.

12 W. Liu, H. Yi, Q. Zheng, X. Li and H. Zhang, J. Mater. Chem. A, 2017, 5 10928-10935.

13 H. Yi, M. Ling, W. Xu, X. Li, Q. Zheng and H. Zhang, Nano Energy, 2018, 47, 340-352.

14 Y. Zhang, S. Guo and H. Xu, J. Mater. Chem. A, 2018, 6, 4525-4534.

15 N. Kosova, D. Rezepova and N. Montroussier, Batteries, 2018, 4, 32.

16 M. Bianchini, P. Xiao, Y. Wang and G. Ceder, Adv. Energy Mater., 2017, 7, 1700514

17 I. L. Matts, S. Dacek, T. K. Pietrzak, R. Malik and G. Ceder, Chem. Mater., 2015, 27, 6008-6015.

18 F. Lalère, V. Seznec, M. Courty, R. David, J. N. Chotard and C. Masquelier, J. Mater. Chem. A, 2015, 3, 16198-16205.

19 A. E. Danks, S. R. Hall and Z. Schnepp, Mater. Horiz., 2016, 3, 91-112

20 M. Bianchini, N. Brisset, F. Fauth, F. Weill, E. Elkaim, E. Suard, C. Masquelier and L. Croguennec, Chem. Mater., 2014, 26, 4238-4247.

21 J. Le Meins and G. Courbion, J. Solid State Chem., 1999, 148, 260-277. 
Journal Name

22 Y. Qi, L. Mu, J. Zhao, Y. S. Hu, H. Liu and S. Dai, Angew. Chemie - Int. Ed., 2015, 54, 9911-9916. 